\title{
Activity and community structures of sulfate- reducing microorganisms in polar, temperate and tropical marine sediments
}

\author{
Alberto Robador ${ }^{1,7}$, Albert L Müller², Joanna E Sawicka ${ }^{3}$, David Berry², Casey RJ Hubert ${ }^{4}$, \\ Alexander Loy ${ }^{2,5}$, Bo Barker Jørgensen ${ }^{6}$ and Volker Brüchert ${ }^{3}$ \\ ${ }^{1}$ Department of Biogeochemistry, Max Planck Institute for Marine Microbiology, Bremen, Germany; ${ }^{2}$ Division \\ of Microbial Ecology, Department of Microbiology and Ecosystem Science, University of Vienna, Wien, \\ Austria; ${ }^{3}$ Department of Geological Sciences, Bolin Centre for Climate Research, Stockholm University, \\ Stockholm, Sweden; ${ }^{4}$ School of Civil Engineering and Geosciences, Newcastle University, Newcastle upon \\ Tyne, UK; ${ }^{5}$ Austrian Polar Research Institute, Vienna, Austria and ${ }^{6}$ Department of Bioscience, Center for \\ Geomicrobiology, Aarhus University, Aarhus C, Denmark
}

\begin{abstract}
Temperature has a fundamental impact on the metabolic rates of microorganisms and strongly influences microbial ecology and biogeochemical cycling in the environment. In this study, we examined the catabolic temperature response of natural communities of sulfate-reducing microorganisms (SRM) in polar, temperate and tropical marine sediments. In short-term sediment incubation experiments with ${ }^{35} \mathrm{~S}$-sulfate, we demonstrated how the cardinal temperatures for sulfate reduction correlate with mean annual sediment temperatures, indicating specific thermal adaptations of the dominant SRM in each of the investigated ecosystems. The community structure of putative SRM in the sediments, as revealed by pyrosequencing of bacterial 16S rRNA gene amplicons and phylogenetic assignment to known SRM taxa, consistently correlated with in situ temperatures, but not with sediment organic carbon concentrations or $\mathrm{C}: \mathrm{N}$ ratios of organic matter. Additionally, several species-level SRM phylotypes of the class Deltaproteobacteria tended to co-occur at sites with similar mean annual temperatures, regardless of geographic distance. The observed temperature adaptations of SRM imply that environmental temperature is a major controlling variable for physiological selection and ecological and evolutionary differentiation of microbial communities.
\end{abstract}

The ISME Journal (2016) 10, 796-809; doi:10.1038/ismej.2015.157; published online 11 September 2015

\section{Introduction}

Microorganisms in the natural environment cope with changing and sometimes hostile conditions that require a wide range of metabolic adaptations (Neidhardt et al., 1990). Microorganisms that are physiologically best adapted to exploit prevailing physical, chemical and biological factors will predominate, which can lead to varying patterns of microbial diversity over different temporal and spatial scales (Prosser et al., 2007). The convergence of ecological and evolutionary timescales is substantiated by the observation of biogeographic patterns in microbial diversity (Hanson et al., 2012). For example, latitudinal gradients of microbial diversity associated with temperature have been

Correspondence: A Robador, CDEBI, University of Southern California, 3616 Trousdale Pkwy, Los Angeles, CA 90089, USA.

E-mail: robadora@usc.edu

${ }^{7}$ Current address: University of Southern California, Los Angeles, CA 90089, USA

Received 18 December 2014; revised 18 April 2015; accepted 25 July 2015; published online 11 September 2015 observed in marine free-living microbial taxa (Fuhrman, 2009). However, it is not well known whether the same applies to microorganisms in benthic environments. The data available on marine sediments are scarce and the correlation of the expression of microbial metabolism and cooccurrence of microbial taxa with environmental temperatures is largely unknown.

Over seasonal time scales, the rates of microbial sulfate reduction strongly correlate with changes in sediment temperature (Jørgensen, 1977; Aller and Yingst, 1980; Moeslund et al., 1994; Kristensen et al., 2000), indicating a response of the metabolic activity of the sulfate-reducing community to ambient temperatures. It has been observed that organic matter limitation has a regulating effect on the temperature dependence of sulfate reduction in marine sediments, as the availability of reactive organic matter becomes the overriding limiting factor (Kostka et al., 1999; Sawicka et al., 2012). However, recent studies support the notion that the short-term thermal response of sulfate reduction is related to the metabolic temperature adaptations of the individual 
sulfate-reducing microbial populations (Robador et al., 2009; Sawicka et al., 2012).

Studies on the temperature dependence of sulfate reduction in different climatic regions have shown that sulfate-reducing microorganisms (SRM) at high latitudes, that is, in Arctic and Antarctic marine sediments, are predominantly psychrophilic (Isaksen and Jørgensen, 1996; Sagemann et al., 1998), while SRM in temperate sediments at lower latitudes are mostly mesophilic (Isaksen et al., 1994). Yet, the available phylogenetic data on sedimentary SRM communities (for example, Ravenschlag et al., 1999; Leloup et al., 2007, 2009) have been insufficient to reveal diversity distribution patterns that would associate with different temperature regimes.

In this study, we explored how temperature controls the anaerobic respiration rate of natural communities of SRM by means of short-term incubation experiments with ${ }^{35} \mathrm{~S}$-sulfate in a thermal gradient using sediment samples from a wide range of geographic regions that differ with respect to the prevailing temperature. Furthermore, we studied the in situ diversity of the corresponding SRM communities by analyzing bacterial 16S rRNA gene amplicon pyrosequencing libraries for the presence of sequences of known sulfate-reducing lineages. We found distinct patterns of metabolic adaptations to environmental temperatures that coincided with the presence of specific SRM populations at sites with similar mean annual temperatures.

\section{Materials and methods}

\section{Study sites}

Marine sediment samples for the present work ranged from polar regions to temperate and tropical latitudes. Brief descriptions of the study sites are provided in Table 1. Samples were obtained from the upper $15 \mathrm{~cm}$ of sediment from each site, which corresponds to the depth range where bacterial sulfate reduction peaks (Abed et al., 2006; Mazumdar et al., 2007; Kristensen et al., 2008; Niemann et al., 2009; Robador et al., 2009; Sawicka et al., 2010; Holmkvist et al., 2014; Xu et al., 2014). After sampling, sediments were kept under anoxic conditions at in situ temperatures until further processing in the laboratory, which occurred within 1 week of sampling. Our earlier experiments have shown that 1 week is too short for the SRM communities to grow or change detectably (Robador et al., 2009).

\section{Index properties and elemental analysis}

Wet-bulk density and porosity were calculated from one sediment sample, taken at each sampling site. Measurements were based on the ratio between the wet and dry masses and density of the sample.

Elemental analyses were performed on triplicate samples of $20-100 \mathrm{mg}$ of freeze-dried and ground sediment. Total carbon and total nitrogen content were determined using a Fisons NA 1500 (Series 2) elemental analyzer (Thermo scientific, Inc., Waltham, MA, USA). Freeze-dried material was combusted with vanadium pentoxide catalyst at $900-1000^{\circ} \mathrm{C}$ in a stream of oxygen and the produced gases were separated by gas chromatography and quantified with a thermal conductivity detector.

Total inorganic carbon was determined by coulometry using a CM5240 TIC acidification module attached to a CM5014 $\mathrm{CO}_{2}$ analyzer (UIC, Inc., Joliet, IL, USA), which measures $\mathrm{CO}_{2}$ evolved from sample acidification. Total organic carbon in the sediments was determined from the difference between total carbon and total inorganic carbon.

\section{Temperature-gradient experiments}

Sediment slurries were prepared by diluting sediment 1:1 (vol/vol) with anoxic artificial seawater prepared as described by Widdel and Bak (1992). Slurries were prepared under $\mathrm{N}_{2}$, and $5 \mathrm{ml}$ of slurry was transferred into each Hungate tube. Hungate tubes were flushed with $\mathrm{N}_{2}$ according to the Hungate technique (Bryant, 1972) and sealed with butyl rubber stoppers. Sediment slurries in Hungate tubes were incubated in an aluminum temperature-gradient block heated electrically at one end and cooled at the other end with a refrigerated and thermostated water bath. Hungate tubes were pre-incubated for at least $5 \mathrm{~h}$ to allow them to reach thermal equilibrium. Triplicate samples were incubated in parallel (at the same temperature) at several points along the temperature gradient block to confirm the reproducibility of sulfate reduction rates (SRR). The temperature span was from $0^{\circ}$ to $+50^{\circ} \mathrm{C}$ to cover the potential physiological temperature range of the active microorganisms. The incubation temperature gradient for the Arctic Ocean (Ymerbukta, Svalbard), North Sea and Baltic Sea sites (Table 1) was extended to $-10^{\circ} \mathrm{C}$ to explore the physiological limits of microorganisms at temperatures below the freezing point.

Measurements of bacterial sulfate reduction were performed using ${ }^{35} \mathrm{~S}$-sulfate according to Kallmeyer et al. (2004) and Roy et al. (2014). To minimize bacterial growth and reoxidation of radiolabeled sulfate during the experiment, the incubation time with the radiotracer was restricted to $24 \mathrm{~h}$. Growth of SRM in marine sediments is too slow to generate significant changes in the community during the short pre-incubation (Hoehler and Jørgensen, 2013).

\section{Temperature dependence}

The Arrhenius equation (Arrhenius, 1908) was applied to model the temperature dependence of SRR. Arrhenius curves were obtained from temperature-gradient incubation data and represent 


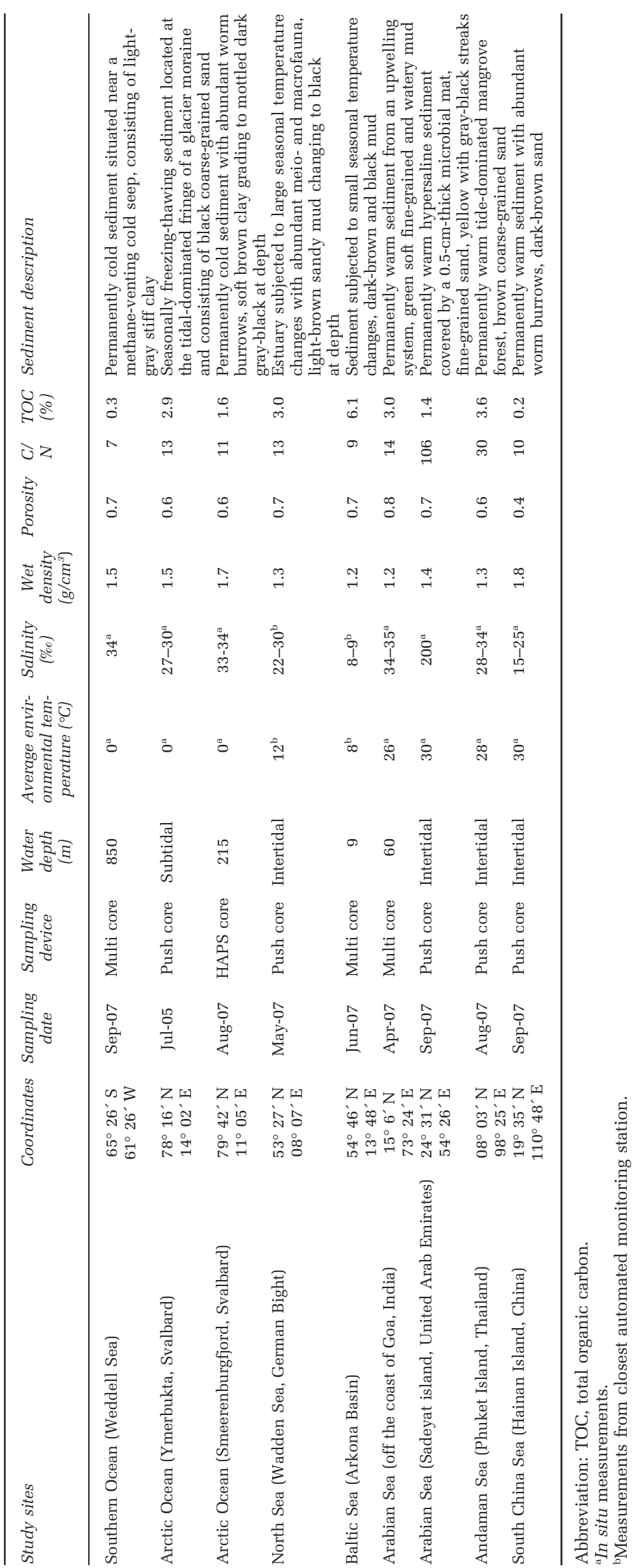


the metabolic rate as a function of temperature as follows:

$\ln (k)=\ln (A)+\left(\frac{-E_{\mathrm{a}}}{R} \times \frac{1}{T}\right)$

where $E_{\mathrm{a}}$ is the activation energy $\left(\mathrm{J} \mathrm{mol}^{-1}\right)$, $k$ is the rate of sulfate reduction $\left(\mathrm{nmol} \mathrm{cm}{ }^{-3} \mathrm{day}^{-1}\right)$, $A$ is the Arrhenius constant, $R$ is the gas constant (8.314 $\mathrm{J} \mathrm{K}^{-1} \mathrm{~mol}^{-1}$ ) and $T$ is the absolute temperature (K). It should be noted that, in a biochemical context, $E_{\text {a }}$ estimated from the slope of the linear temperature ranges is commonly interpreted to reflect the temperature response of the rate-limiting step in a physiological process, for example, membrane transport or enzymatic catalytic conversion. The catalysis of a chemical reaction by an efficient enzyme with low temperature dependence will yield a low $E_{\text {a }}$ (D'Amico et al., 2002; Marx et al., 2007). For naturally occurring microbial communities, $E_{\text {a }}$ values are not activation energies of a single sulfate-reducing population, but are a 'temperature characteristic' and reflect the combined response of a complex SRM community (for example, Figure 1). Despite this complexity, Knoblauch and Jørgensen (1999) found that calculated $E_{\mathrm{a}}$ values for pure cultures of SRM were similar to those estimated for the natural SRM communities in the marine sediments from which these cultures were derived. Coincident $E_{\mathrm{a}}$ values indicate that SRM have similar responses to increasing temperatures in pure cultures and in natural sediments. $E_{\text {a }}$ was therefore used to describe the temperature sensitivity of SRM communities in sediments from different temperature regions.

The temperature dependence can also be described by the temperature coefficient $\left(Q_{10}\right)$, which describes the factor by which rate increases in response to a temperature increase of $10^{\circ} \mathrm{C}$. $Q_{10}$ values were calculated for the $10^{\circ} \mathrm{C}$ interval below the temperature at which SRR were highest in the linear thermal range of Arrhenius plots according to:

$Q_{10}=\exp \left[\frac{E_{a} \times 10}{\operatorname{RT}(T+10)}\right]$

This equation shows that the $Q_{10}$ value, in contrast to the $E_{\mathrm{a}}$ value, depends on which temperature interval is chosen within the linear thermal range of the Arrhenius plot.

Sequence analysis and phylogenetic identification of putative sulfate-reducing bacteria

Bacterial 16S rRNA gene libraries from the same sediment samples used in this study were constructed as part of a previous study (Müller et al., 2014a, b, NCBI Sequence Read Archive accession number SRP028774). These libraries were re-analyzed here focusing on the presence of sequences affiliated with known lineages of SRM. Amplicon pyrosequencing reads were clustered into phylotypes using a 97\% identity threshold with
UCLUST (Edgar, 2010). Representative sequences were aligned with mothur using the NeedlemanWunsch pairwise alignment method default settings (Schloss et al., 2009). Chimeras were detected using Chimera Slayer (Haas et al., 2011) and excluded from further analysis, resulting in 6935 phylotypes across the nine locations. Taxonomy was automatically assigned using the RDP classifier (Wang et al., 2007). In addition, the web-based SINA aligner (Pruesse et al., 2012) was used to automatically align representative phylotype sequences and to determine the most closely related sequences that were then imported into the SILVA SSU Ref NR 111 database (Quast et al., 2013) for phylogenetic analysis in ARB (Ludwig et al., 2004). Short amplicon sequences were added to the SILVA reference tree using the ARB Parsimony Interactive tool. Phylotypes were defined as candidate SRM phylotypes if they clustered phylogenetically with known SRM lineages and/or were assigned to known SRM lineages by the RDP classifier. The alignment of candidate SRM phylotype sequences was manually curated and used to re-cluster the representative sequences into species-level phylotypes of $\geqslant 97 \%$ sequence similarity based on the average neighbor algorithm in mothur (Schloss et al., 2009). A maximum likelihood (RAxML) tree was calculated with almost full-length 16S rRNA sequences $(\geqslant 1400 \mathrm{nt})$ of known SRM $(n=167)$ and most closely related sequences $(n=328)$ based on 1222 alignment positions by using a 50\% sequence conservation filter for bacteria. The candidate SRM phylotype sequences from the amplicon libraries were then added to the tree without changing the overall tree topology using the ARB Parsimony Interactive tool and applying the 50\% conservation filter. This resulted in 384 putative SRM phylotypes that clustered phylogenetically with known SRM lineages and shared $\geqslant 90 \%$ sequence similarity with described SRM species.

\section{Bacterial community analysis}

Pyrosequencing libraries, which contained a median of 5190 reads (min/max: 1024/10 082) and a median of 1028 reads assigned to putative SRM ( $\mathrm{min} / \mathrm{max}$ : $117 / 2323$ ), were rarefied to the smallest library for all analyses (that is, 1024 reads for total communities and 117 reads for SRM). Principal coordinates analysis was performed based on a Bray-Curtis dissimilarity matrix (using presence-absence as well as relative abundance data) using the package 'vegan' in R (Oksanen et al., 2012). The significance of environmental factors affecting community composition was assessed using the non-parameteric perMANOVA (permutational multivariate analysis of variance) test (Anderson, 2001). To assess co-occurrence of SRM phylotypes in multiple sediments, a correlation network was produced from SRM phylotype relative abundance across the nine sites. Briefly, pairwise Pearson correlation 

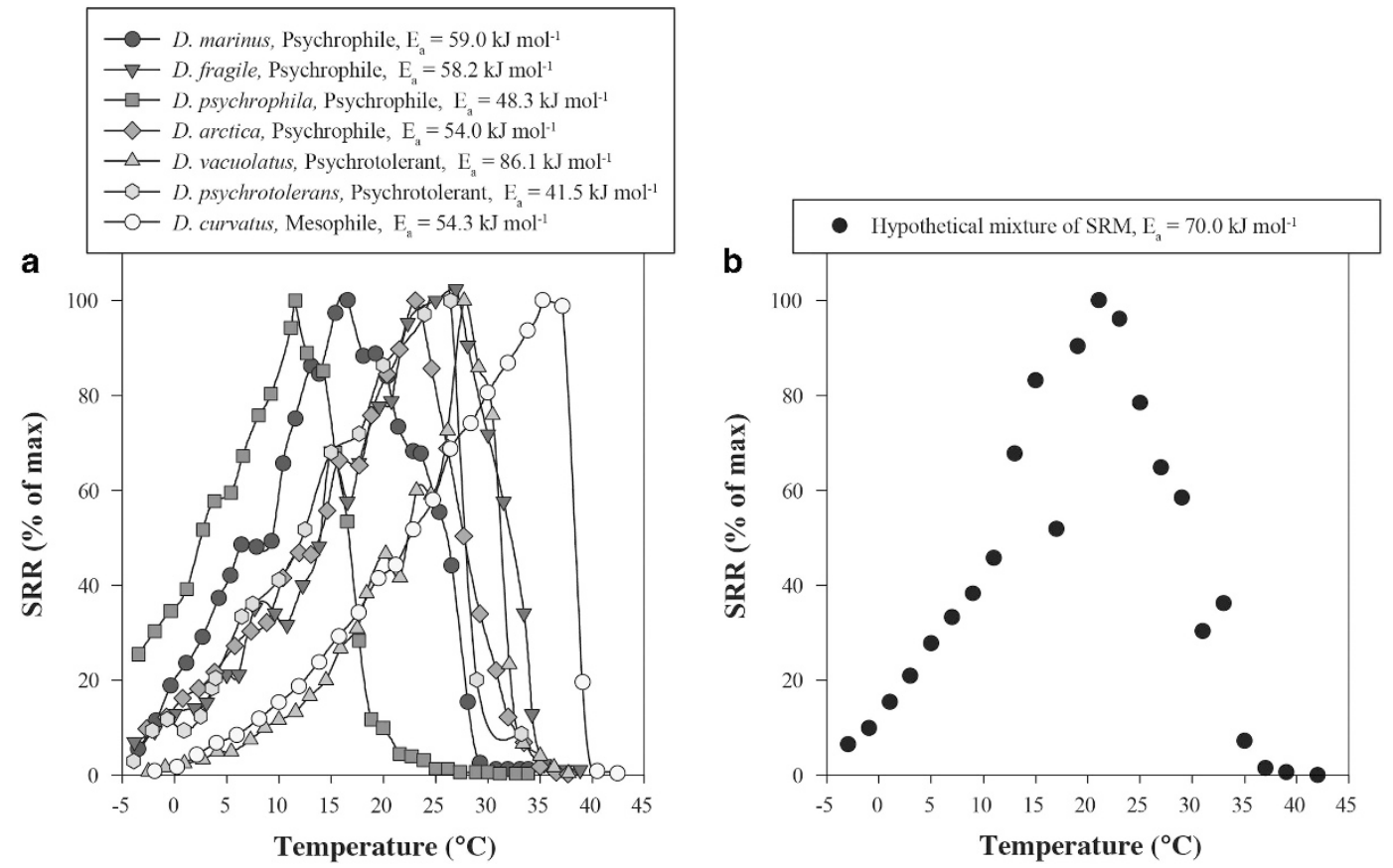

C

Temperature $\left({ }^{\circ} \mathrm{C}\right)$

d

Temperature $\left({ }^{\circ} \mathrm{C}\right)$
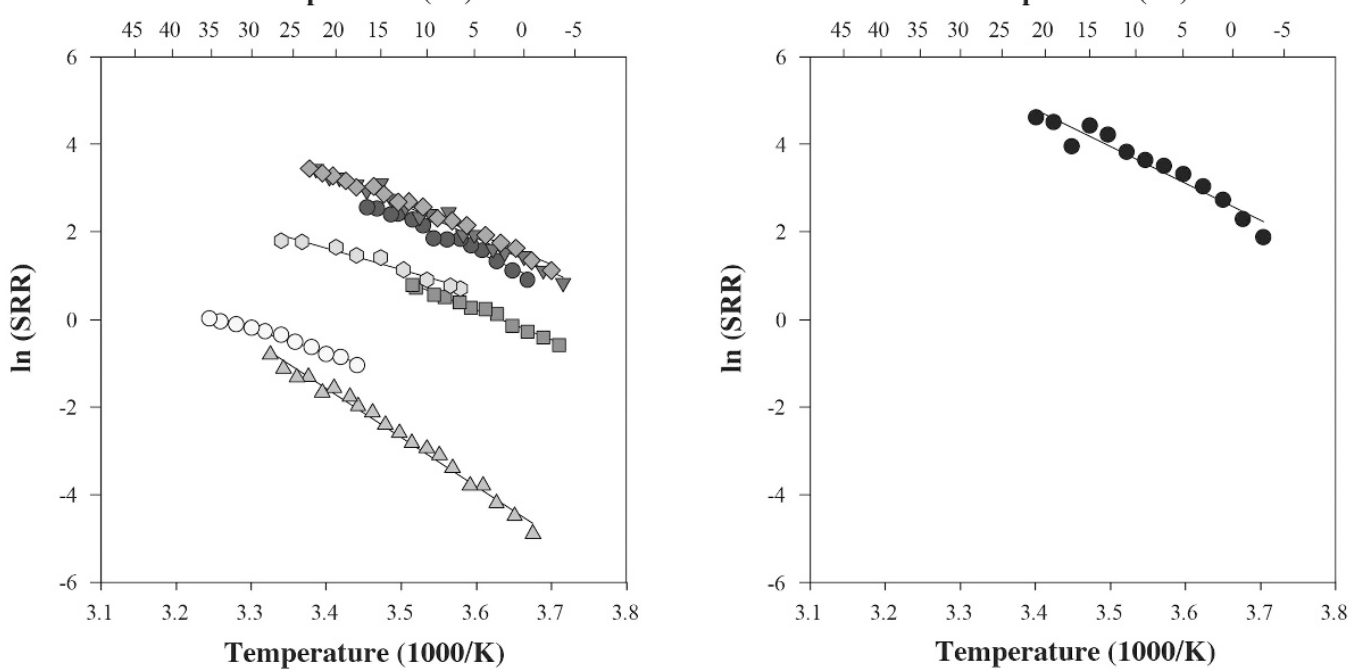

Figure 1 (a) SRR of seven pure cultures of sulfate-reducing bacteria measured in temperature-gradient incubation experiments. Data are from Isaksen and Jørgensen (1996); Knoblauch and Jørgensen (1999); and Tarpgaard et al. (2006). (b) Sum of SRR of the seven strains from (a), calculated at $2{ }^{\circ} \mathrm{C}$ temperature intervals. Equal weight is given to each SRM strain in (a) to illustrate the cumulative effect of a mixed SRM community. The temperature dependence of individual isolates and summed SRRs is presented as Arrhenius plots in (c) and (d), respectively.

coefficients $(r)$ were calculated for phylotypes. The statistical significance of $r$ was determined by generating a null distribution for $r$ by randomly permuting relative abundances across the nine sites for 1000 iterations and calculating the $P$-value of the observed $r$ from the null distribution. $P$-values were corrected for multiple testing using the False Discovery Rate approach (Benjamini and Hochberg, $1995)$ and corrected $P$-values with a value of $\leqslant 0.05$ were used to create a correlation network that was visualized in Cytoscape (Saito et al., 2012). The site occupancy of a phylotype was calculated as the number of sample locations at which the phylotype was detected. The mean temperature at which each phylotype was enriched was calculated by multiplying its relative abundance at each site by the mean temperature at the site, summing these products, and dividing by the sum of abundances over all nine sites. This produced a weighted value signifying the temperature at which the phylotype was most abundant. All calculations were done in $\mathrm{R}$ (Team, 2011). 

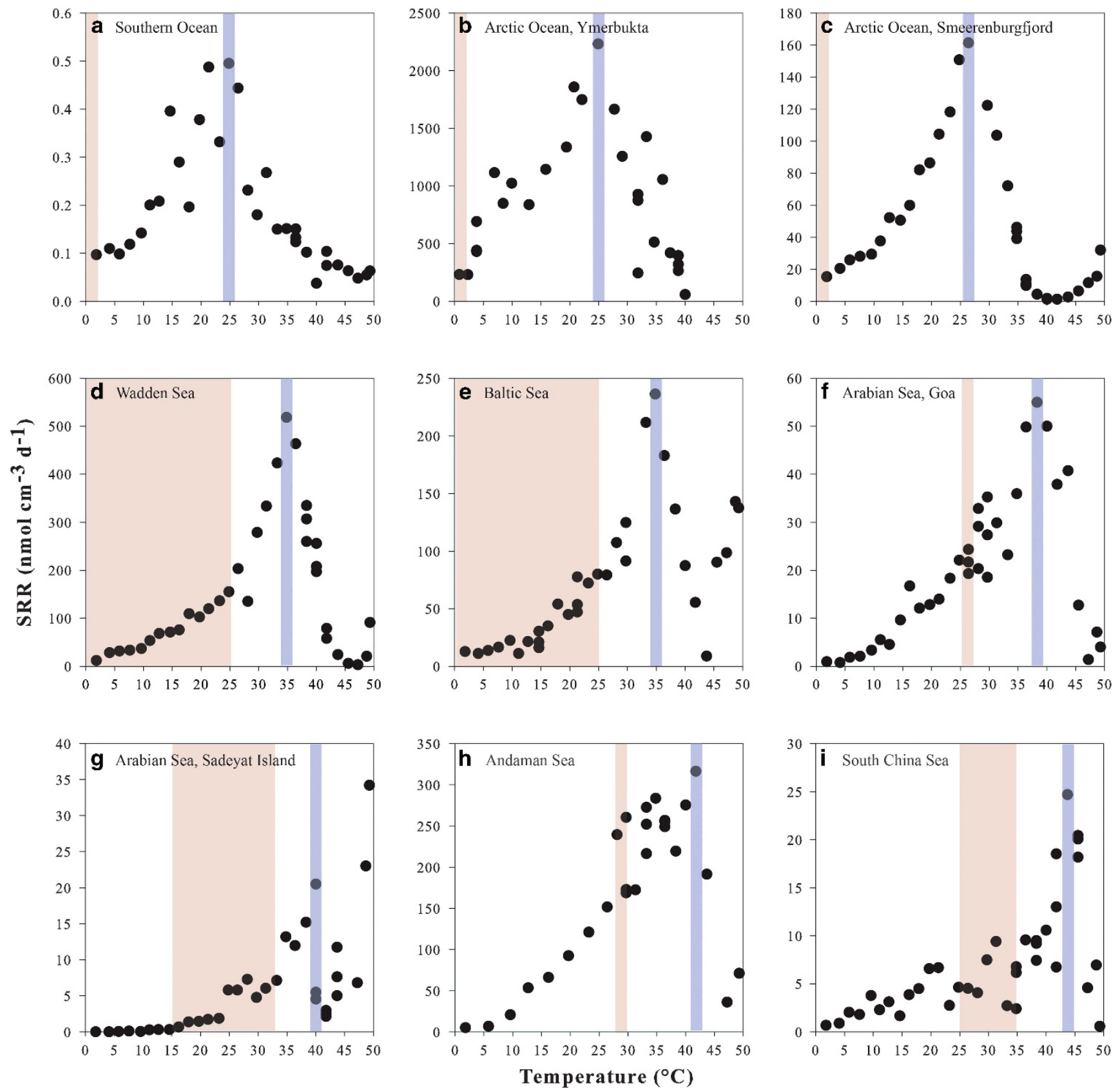

Figure 2 SRR measured in temperature-gradient incubation experiments of sediment slurries from all sampling sites. In situ temperature range is indicated by the area shaded in red, always to the left of the band shaded in blue indicating the $T_{\text {opt }}$ for sulfate reduction.

\section{Results}

Sulfate reduction rates

Sulfate reduction rates (SRR) as a function of temperature were determined for all nine sediments (Figure 2). Sulfate reduction was detected within the studied temperature range $\left(0^{\circ}\right.$ to $\left.+50^{\circ} \mathrm{C}\right)$ for all sediments, including temperatures well outside the in situ range corresponding to the sampled environments. The lowest SRR, 0.1-0.5 $\mathrm{nmol} \mathrm{cm}^{-3} \mathrm{day}^{-1}$, were measured in the sediment with the greatest water depth in the Southern Ocean, Weddell Sea
(Figure 2a and Table 1) while the highest rates, 230$2200 \mathrm{nmol} \mathrm{cm}^{-3}$ day $^{-1}$, were observed in a shallow Arctic Ocean intertidal lagoon, Ymerbukta on Svalbard, characterized by a relatively higher content of organic matter derived from decomposing macrophytes (Figure 2b and Table 1).

The temperature curves for SRR all show a distinct peak corresponding to the optimal temperature $\left(T_{\text {opt }}\right)$ that is, the temperature at which the rates are highest. Arctic and Antarctic sediments showed $T_{\mathrm{opt}}$ for sulfate reduction of $24-26^{\circ} \mathrm{C}$ (Figures 2a-c), which is $25^{\circ} \mathrm{C}$ above the in situ temperatures in 
these sediments. Temperate sediments have broader in situ temperature ranges than polar sediments, and in these samples sulfate reduction was detected from below $0{ }^{\circ} \mathrm{C}$ up to $T_{\text {opt }}$ at $35^{\circ} \mathrm{C}$ (Figures $2 \mathrm{~d}$ and e). The thermal optimum for sulfate reduction in tropical sediments was shifted toward $38-44{ }^{\circ} \mathrm{C}$ (Figures 2f-i).

SRR measured in polar sediments at in situ temperatures of ca. $0^{\circ} \mathrm{C}$ were $9-20 \%$ of the maximal rates (Figures 2a-c and Tables 1 and 2). In temperate sediments, SRR at the mean in situ temperatures of ca. $12{ }^{\circ} \mathrm{C}$ were $9-13 \%$ of maximal rates (Figures $2 \mathrm{~d}$ and e and Tables 1 and 2) while in tropical sediments, SRR at in situ temperatures of $26-30{ }^{\circ} \mathrm{C}$ were $23-76 \%$ of maximal rates (Figures $2 \mathrm{f}-\mathrm{i}$ and Tables 1 and 2).

Several of the studied sediments, irrespective of their in situ temperature, displayed an increase in SRR at temperatures exceeding $40-45^{\circ} \mathrm{C}$, well above the psychrophilic or mesophilic $T_{\mathrm{opt}}$ (Figures 2a and $\mathrm{c}-\mathrm{h}$ ).

Temperature characterization of sulfate reduction The Arrhenius plots are characterized by a range of linear slopes, mostly extending below and above the respective environmental temperature ranges (Figure 3). Apparent $E_{\mathrm{a}}$ values in all sediments ranged between 36 and $97 \mathrm{~kJ} \mathrm{~mol}^{-1}$. $Q_{10}$ values ranged from 1.6 to 3.4 in the $10{ }^{\circ} \mathrm{C}$ temperature range leading to the $T_{\text {opt }}$ (Table 2, Figure 3). In polar and temperate sediments, the linear range of sulfate reduction extended below $0^{\circ} \mathrm{C}$ (Figures $3 \mathrm{a}$ and $\mathrm{b}$ ). The SRR-temperature relationship was linear down to -4 to $-6{ }^{\circ} \mathrm{C}$ (Figure 4), which is at the freezing range for the sediment slurries. Rates thus dropped off steeply below this temperature range. By contrast, in sediments from tropical latitudes, with the exception of the South China Sea, $E_{\text {a }}$ remained constant over a linear range that extended from the $T_{\text {opt }}$ down to an apparent transition between +4 and $+18^{\circ} \mathrm{C}$ (Figures $3 \mathrm{~d}$ and $\mathrm{f}-\mathrm{i}$ ). Below these temperatures the slope changed sharply to higher $E_{\mathrm{a}}$ values of $130-234 \mathrm{~kJ} \mathrm{~mol}^{-1}\left(Q_{10}, 5.7-23\right)$. The temperature at which the $E_{\mathrm{a}}$ values changed was estimated by calculating the best-fit line for the experimental data using linear regression analysis. The temperature at the intersection of the two lines is here defined as the critical temperature $\left(T_{\text {crit }}\right)$.

\section{Diversity and colocalization of SRM phylotypes in marine sediments}

All but one of the 384 putative SRM phylotypes were affiliated with the class Deltaproteobacteria and accounted for $9.7-25.9 \%$ of the total bacterial $16 \mathrm{~S}$ rRNA gene sequences from the nine marine sediment samples (Figure 5, Supplementary Figures S1 and S2). SRM phylotype diversity in all nine samples was dominated by members of the Desulfobacteraceae, Desulfobulbaceae and Desulfatiglans anilini lineage (Müller et al., 2014a, b) (Figures 5a and b, Supplementary Figure S2). A slight exception to this pattern is the sediment sample from Sadeyat, which contained less Desulfobulbaceae but a substantial fraction of Desulfohalobiaceae, a family that comprises many halophilic SRM species (Kjeldsen et al., 2007), which is consistent with the higher salinity of this sediment.

Principal coordinates analysis of total bacterial communities using the Bray-Curtis metric revealed clustering of sites by mean temperature, when either presence/absence or relative abundance was used to calculate sulfate-reducing and total community dissimilarities between locations (Figure 6). The one exception to this tight clustering by temperature was the saline Sadeyat sediment sample. To evaluate which environmental parameters were important in shaping the community compositions, a nonparametric perMANOVA was applied to test the significance of temperature, salinity, C:N ratio, total organic carbon and activation energy for sulfate

Table 2 Summary of temperature gradient experiments based on data from Figure 2

Study sites

Sulfate reduction Sulfate reduction rates $\left(\mathrm{nmol} \mathrm{cm}^{-3}\right.$ day $\left.^{-1}\right) \quad \mathrm{E}_{a}\left(\mathrm{~kJ} \mathrm{~mol}^{-1}\right) \quad Q_{10^{a}}$

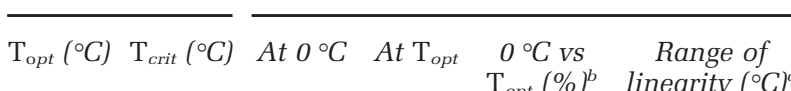

Southern Ocean (Weddell Sea)

Arctic Ocean (Ymerbukta, Svalbard)

Arctic Ocean (Smeerenburgfjord, Svalbard)

North Sea (Wadden Sea, German Bight)

Baltic Sea (Arkona Basin)

Arabian Sea (off the coast of Goa, India)

Arabian Sea (Sadeyat island, United Arab Emirates)

South China Sea (Hainan Island, China)
Andaman Sea (Phuket Island, Thailand)

$\begin{array}{lc}21.3 & \text { N/A } \\ 24.9 & \text { N/A } \\ 26.4 & \text { N/A } \\ 34.8 & \text { N/A } \\ 34.8 & \text { N/A } \\ 38.3 & 11 \\ 40 & 18 \\ 41.8 & 13 \\ 43.7 & 8\end{array}$

Abbreviations: SRR, sulfate reduction rates; $T_{\text {crit }}$ critical temperature; $T_{\mathrm{op}}$, optimal temperature

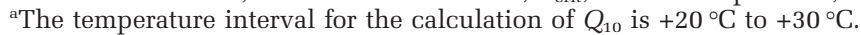

bPercentage of SRR at $0^{\circ} \mathrm{C}$ of maximum SRR at $T_{\mathrm{opt}}$.

'The term 'Range of linearity' refers to the linear part of the Arrhenius plot. 


\section{Temperature $\left({ }^{\circ} \mathrm{C}\right)$}

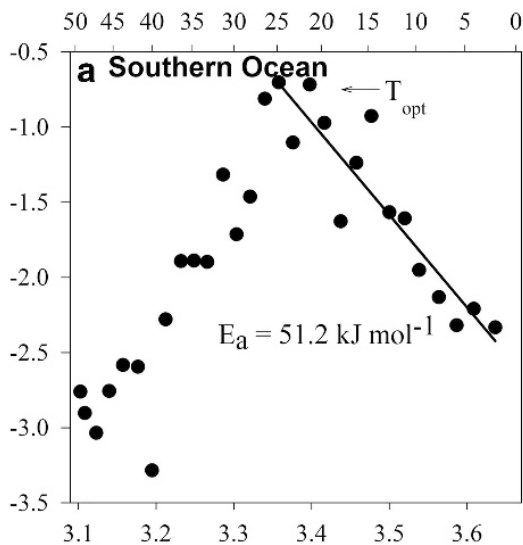

$\begin{array}{lllllllllll}50 & 45 & 40 & 35 & 30 & 25 & 20 & 15 & 10 & 5 & 0\end{array}$
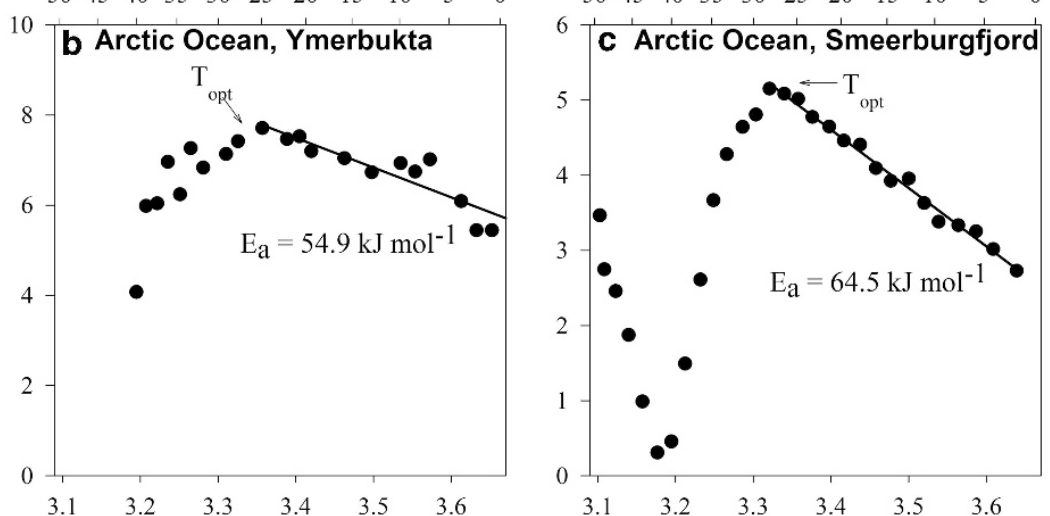

$\begin{array}{lllllllllll}50 & 45 & 40 & 35 & 30 & 25 & 20 & 15 & 10 & 5 & 0\end{array}$
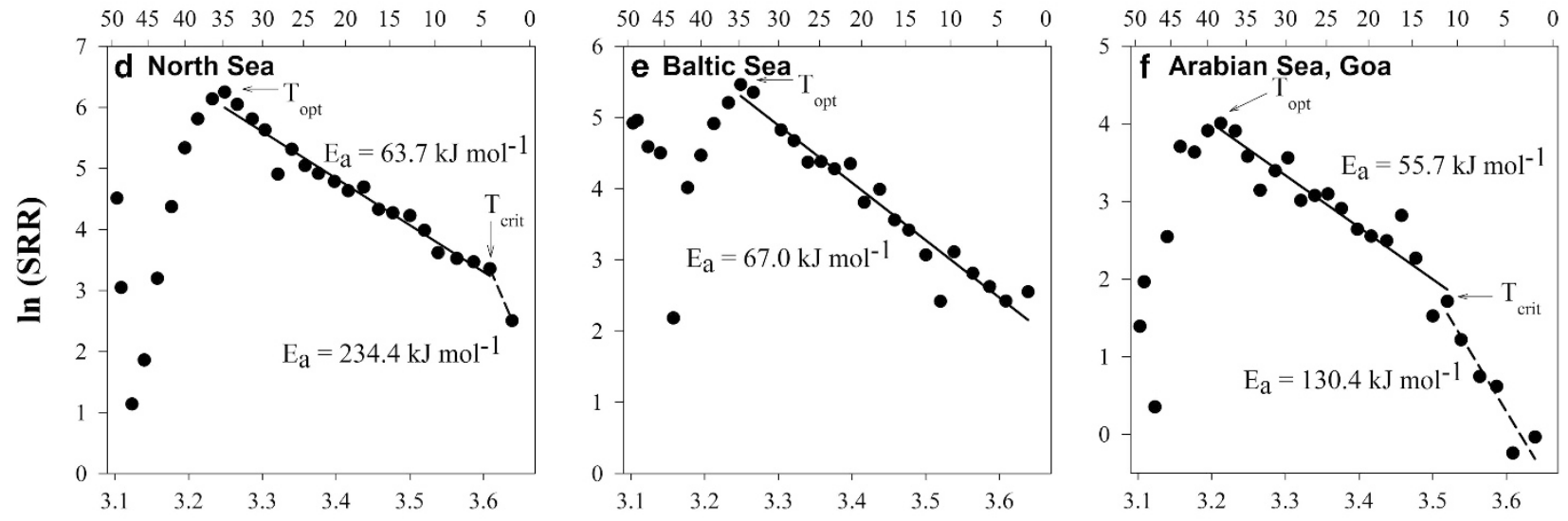

$\begin{array}{lllllllllll}50 & 45 & 40 & 35 & 30 & 25 & 20 & 15 & 10 & 5 & 0\end{array}$

$\begin{array}{lllllllllll}50 & 45 & 40 & 35 & 30 & 25 & 20 & 15 & 10 & 5 & 0\end{array}$

$\begin{array}{lllllllllll}50 & 45 & 40 & 35 & 30 & 25 & 20 & 15 & 10 & 5 & 0\end{array}$
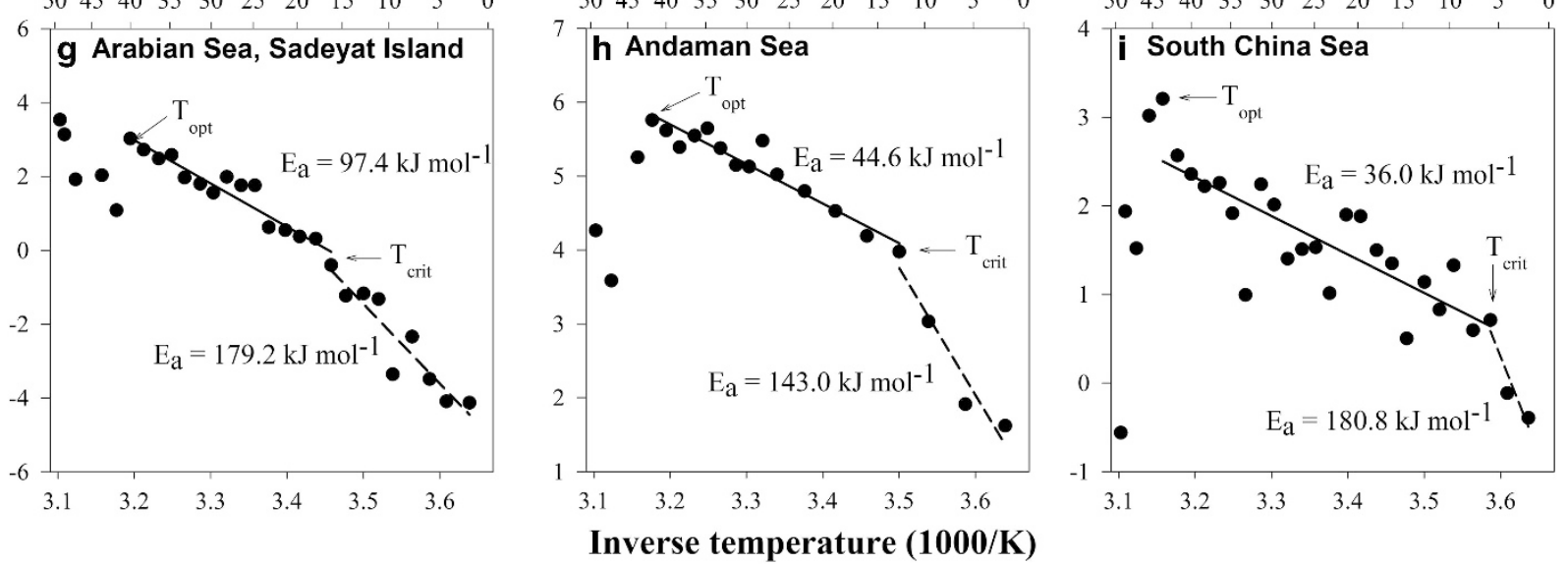

Figure 3 Arrhenius plots of data from Figure 1. Corresponding $E_{\mathrm{a}}$ values are shown.

reduction. Temperature and salinity, but not the other factors, were significantly associated with SRM community composition (perMANOVA, $P<0.001$, Table 1).

To evaluate colocalization of individual SRM phylotypes across the nine sites, a correlation network based on the abundance of SRM phylotypes relative to the entire SRM community was developed. Strong clustering of phylotypes into nine modules, that is, clusters of co-occurring phylotypes, was observed (Figure 7). Many phylotypes associated with each module were enriched at only one site. Consistent with the principal coordinates analysis, phylotype modules clustered in the overall network according to mean temperature. Several phylotypes detected at multiple sites (that is, site occupancy $>1$ ) were correlated with other phylotypes in multiple modules (that is, phylotypes that represent links between modules in the network), and these correlations were predominantly between modules 
associated with sites having similar mean temperatures. Some module-connecting phylotypes (for example, Desulfobulbaceae phylotypes 195, 1511 and 2651; Desulfatiglans anilini lineage phylotypes 5671 and 4726) were characteristic of sediments with cold temperatures, while others (Desulfobacteraceae phylotypes 134, 1263 and 5726; Desulfobulbaceae phylotypes 2510 and 6454; Desulfoarculus baarsii lineage phylotype 1201; Desulfobacca acetoxidans lineage phylotype 5807) were characteristic of sediments with warmer temperatures. The phylotype module associated with the warm and high-salinity site, Sadeyat, was unique and disconnected from all other sites. No trend was observed with respect to taxonomic affiliation and co-occurrence of phylotypes (data not shown).

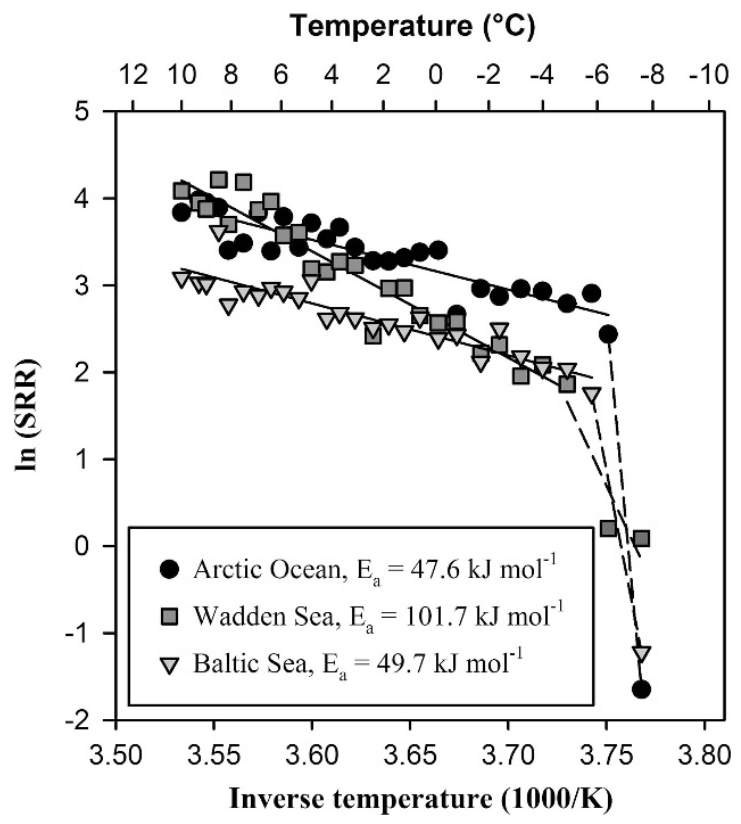

Figure 4 Arrhenius plots of SRR $\left(\mathrm{nmol} \mathrm{cm}^{-3}\right.$ day $\left.^{-1}\right)$ measured in temperature-gradient incubation experiments down to $-10^{\circ} \mathrm{C}$ of sediment slurries from sampling sites at the Arctic Ocean (Smeerenburgfjord, Svalbard), Wadden Sea and Baltic Sea.

\section{Discussion}

Temperature response and diversity of SRM are site specific

The temperature response of microbial respiration and growth has commonly been determined in temperature-gradient incubation experiments (Battley, 1964) where the thermal response of an individual organism can be described using three cardinal temperatures (Neidhardt et al., 1990). The minimum temperature $\left(T_{\min }\right)$ and maximum temperature $\left(T_{\max }\right)$ delimit the range of growth, while the optimum temperature ( $T_{\text {opt }}$ ) denotes the temperature at which the growth rate is highest. On the basis of these defining cardinal parameters, microorganisms are frequently divided into broad classes: psychrophilic $\left(T_{\min }<0^{\circ} \mathrm{C}, T_{\mathrm{opt}} \leqslant 15^{\circ} \mathrm{C}, T_{\max } \leqslant 20^{\circ} \mathrm{C}\right)$, psychrotolerant $\left(T_{\min } \leqslant 0^{\circ} \mathrm{C}, T_{\text {opt }} \leqslant 25^{\circ} \mathrm{C}, T_{\max } \leqslant 35^{\circ} \mathrm{C}\right)$, mesophilic $\left(T_{\text {opt }} \sim 25-40^{\circ} \mathrm{C}, T_{\max } \sim 35-45^{\circ} \mathrm{C}\right)$ and thermophilic $\left(>45^{\circ} \mathrm{C}\right.$ ) (Morita, 1975). In the case of complex SRM communities in marine sediments, their temperature response can be interpreted as the combination of SRR of many different SRM populations, each with a given set of cardinal temperatures. Such a mixed community response is illustrated in Figure 1, where the SRR of different psychrophilic, psychrotolerant and mesophilic sulfate-reducing strains (Figure 1a) are summed to give a theoretical temperature response of a mixed SRM community (Figure 1b). As an example, a hypothetical mixture of SRM (Figure 1b), each with characteristic temperature ranges but predominantly psychrophilic, results in a relatively broad temperature response similar to that observed for many natural communities in cold sediments (Isaksen and Jørgensen, 1996; Sagemann et al., 1998). The composite of the temperature responses of these organisms (Figure 1c) translates into a temperature characteristic with an average $E_{\mathrm{a}}$ of $70 \mathrm{~kJ} \mathrm{~mol}^{-1}$ (Figure 1d), corresponding to a $Q_{10}$ of 2.6.

These values fall within the range for active SRM (Isaksen and Jørgensen, 1996; Sagemann et al., 1998) as well as other heterotrophic bacterial communities a

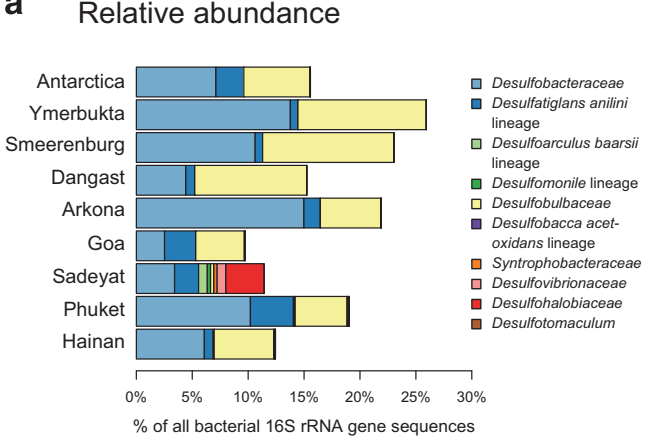

b Number of phylotypes

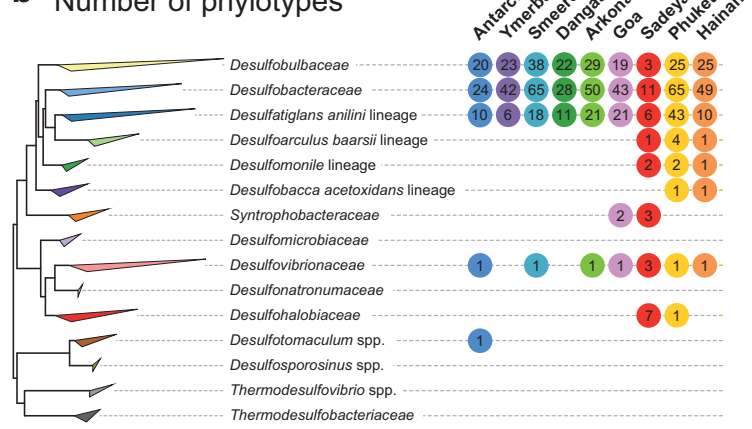

Figure 5 (a) Relative abundance of 16S rRNA gene sequences of putative SRM, which were inferred from phylogenetic relationships to known SRM; (b) Maximum likelihood (RAxML) tree of SRM. Taxa and lineages of known SRM are clustered and the numbers of associated phylotypes present at each location are shown. 
a

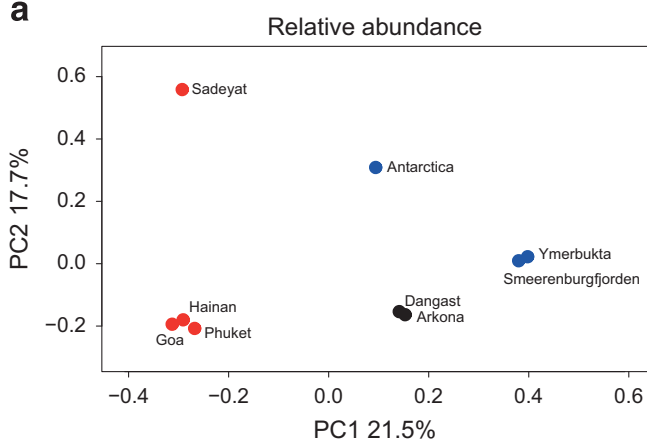

b

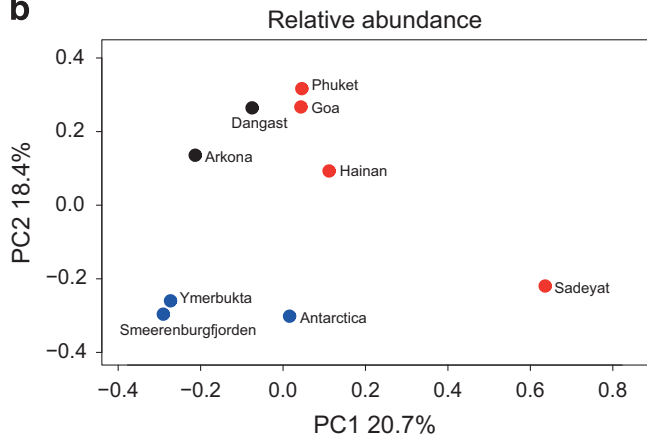

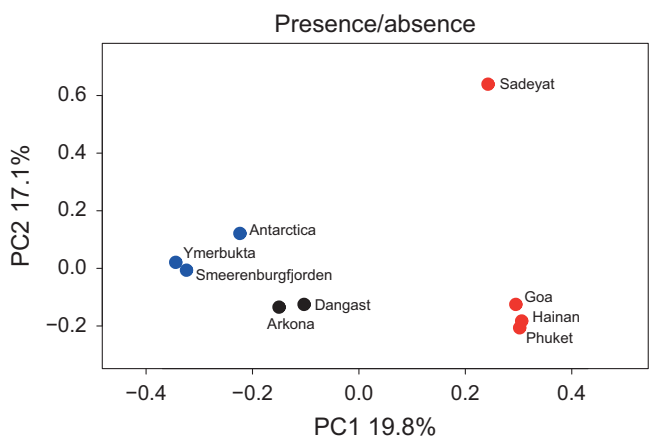

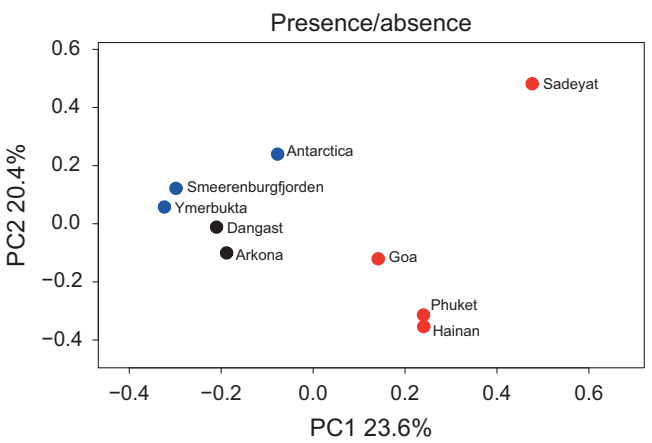

Figure 6 Principal coordinates analysis (PCoA) of putative SRM communities (a) and total bacterial communities (b) at each sediment site based on the Bray-Curtis distance metric (both relative abundance and presence-absence variants of the metric). Sites are colored by sampling region into polar (blue), temperate (black) and tropical (red) regions.

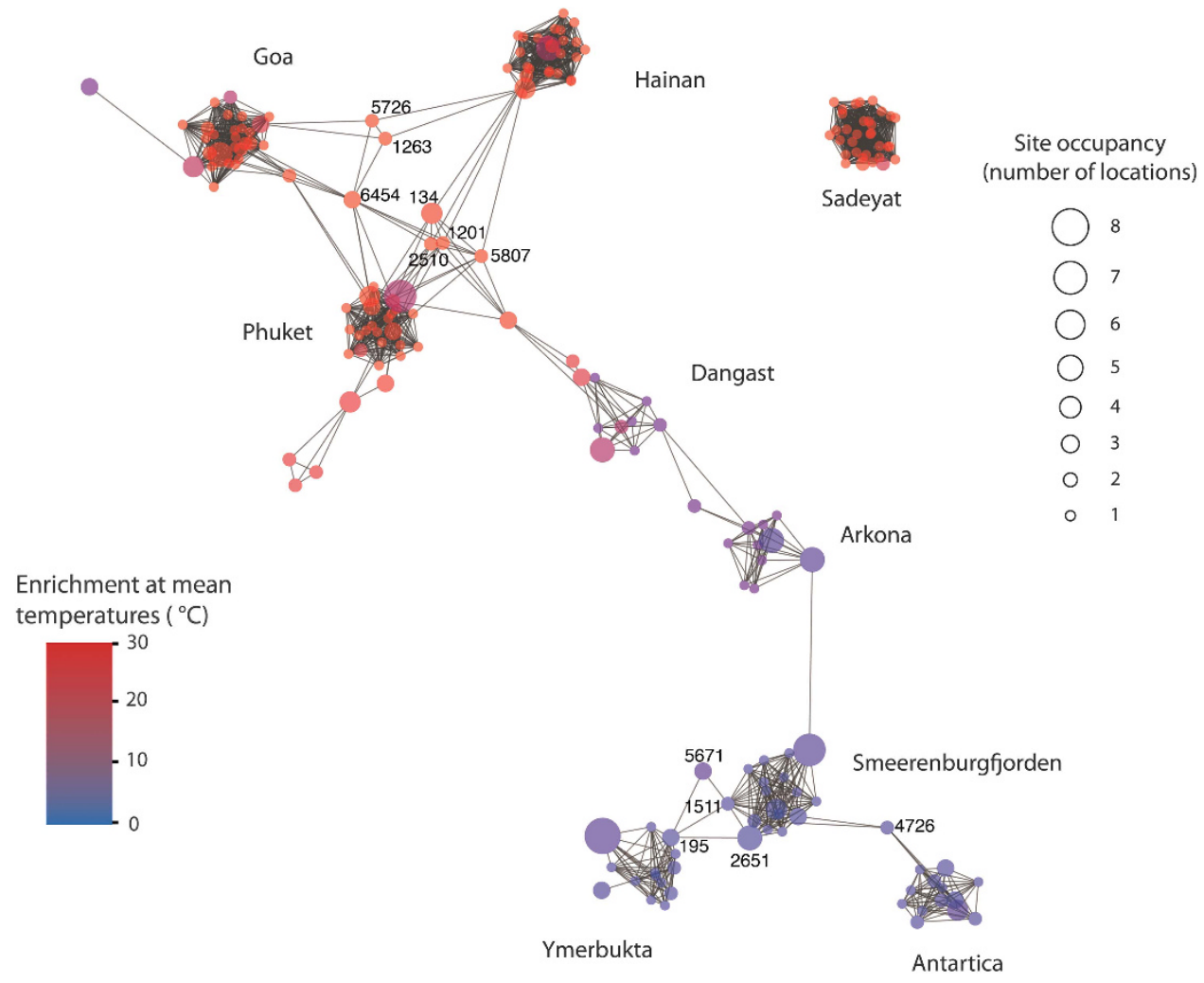

Figure 7 Correlation network analysis using the abundance of SRM phylotypes relative to the entire SRM community. Each node (i.e., circle) represents a phylotype and each edge (i.e., gray line) represents a statistically significant positive correlation between two nodes. Nodes were colored according to the mean sediment temperature at which each phylotype was enriched and their size was scaled according to site occupancy. Aside from a single Desulfotomaculum phylotype from Antarctica, all SRM were affiliated with the class Deltaproteobacteria. 
(Pomeroy and Wiebe, 2001). Accordingly, the regulation of $T_{\text {opt }}$ for sulfate reduction by mean ambient temperatures (Figure 2) denotes the dominant temperature sensitivities of the active SRM community in the studied environments and is indicative of the enrichment of particular SRM. In this study, we present new data and extend previous findings (for example, Isaksen and Jørgensen, 1996; Arnosti et al., 1998; Sagemann et al., 1998; Canion et al., 2014) that suggested temperature-dependent adaptations of SRM communities based on whole-community SRR. Moreover, our observations reveal that the environment selects organisms that are physiologically best adapted to the prevailing temperature.

SRR measured at the in situ temperature in polar sediments $\left(0^{\circ} \mathrm{C}\right)$ were $9-20 \%$ of the maximal rates at $T_{\text {opt }}$ (Figures 2a-c, Table 2). By comparison, in temperate sediments, the relative SRR at $0{ }^{\circ} \mathrm{C}$ were only $2-5 \%$ of the rates at $T_{\text {opt }}$ (Figures $2 \mathrm{~d}$ and e and Table 2). Relatively high metabolic rates at temperatures near the freezing point are characteristic of microorganisms adapted to cold habitats (Harder and Veldkamp, 1968). The SRR at $0^{\circ} \mathrm{C}$ relative to $T_{\text {opt }}$ in the polar sediments are in the range previously described for psychrophilic sulfate-reducing microbial communities in cold polar marine sediments (Isaksen and Jørgensen, 1996; Robador et al., 2009). This shows a distinct adaptation of SRM to the low temperature in the polar region. Of the three polar environments, the Antarctic sediment had the highest relative SRR at low temperatures $(20 \%$ of SRR at $T_{\text {opt }}$; Figure 2, Table 2). Arctic sediments collected from Smeerenburgfjorden and Ymerbukta on the west coast of Svalbard are influenced by the slightly higher temperatures of the North Atlantic Water compared with Antarctic waters (Walczowski and Piechura, 2007), which may explain the broader temperature adaptation range of the Arctic SRM communities. Similar response patterns to water temperatures have been observed in permanently but moderately cold sediments from temperate regions, where sulfate reduction showed a mesophilic temperature response (Isaksen and Jørgensen, 1996). Sediments with seasonally changing temperatures are only exposed to low temperature during winter, whereas the psychrotolerant and mesophilic community develops primarily in summer when temperatures are warmer and the influx of organic matter is greater. Psychrophiles may be better adapted to winter conditions, but with a mean cell turnover time of about 1 year (Hoehler and Jørgensen, 2013), they apparently grow too slowly for a 'winter community' to develop. Psychrotolerants and mesophiles predominate in temperate habitats even at low temperatures during winter (Robador et al., 2009). In tropical sediments, high SRR at in situ temperatures relative to $T_{\text {opt }}(23-76 \%$, Figure 2, Table 2) suggest that a mesophilic SRM community dominates these environments with an optimal activity close to the ambient temperature. The permanently warm conditions in these environments select for a community adapted to temperatures that remain above $10-15{ }^{\circ} \mathrm{C}$ and are generally $25-30^{\circ} \mathrm{C}$.

Relative rates of sulfate reduction at $45-50{ }^{\circ} \mathrm{C}$ are $13-148 \%$ of highest rates in all but the intertidal Arctic Sea and South China Sea sediments, indicating the presence of spores of thermophilic SRM that germinated at these high temperatures, even though these study sites would not support in situ growth at their ambient temperatures. Thermophilic sporeforming bacteria, among them SRM, have been reported from a variety of marine environments ranging from high Arctic to temperate environments (Isaksen et al., 1994; Hubert et al., 2009; de Rezende et al., 2013; Mueller et al., 2014). Their distribution patterns are suggested to be linked to a combination of dispersal by ocean currents, regional hydrography and local geological factors.

This distinct physiological differentiation of SRM communities in polar, temperate and tropical regions is consistent with differences in phylotype composition among the nine study sites (Figure 5). SRM and total community phylotypes from remotely isolated samples exhibit patterns of diversity related to similar mean environmental temperatures (Figure 6, Supplementary Table S1). Our data suggest that, despite the high abundance and potentially high dispersal of microorganisms, the prevailing ambient temperature exerts strong environmental selection on microbial community composition in marine sediments.

Respiration rates and community structure of SRM are determined by temperature

In sediments investigated here, the temperature dependence of the short-term SRR was linear extending from the lower temperature limit of sulfate reduction, which varied according to the observed $T_{\text {crit }}$, up to the $T_{\text {opt }}$ (Figures 3 and 4). The $E_{\text {a }}$ of $36-97 \mathrm{~kJ} \mathrm{~mol}^{-1}$ (Figure 3 and Table 2) is within the range of apparent $E_{\text {a }}$ estimated in seasonal studies of shallow coastal marine sediments, $36-132 \mathrm{~kJ} \mathrm{~mol}^{-1}$ (Westrich and Berner, 1988). Below the $T_{\text {crit }}$, SRR decreased abruptly exhibiting a stronger temperature dependency, that is, higher $E_{a}$ values (Figure 3). This can be attributed to a different physiological temperature regulation of sulfate reduction below the $T_{\text {crit }}$ and shows that some SRM were stressed below the temperature range to which they are adapted. The existence of a critical temperature $\left(T_{\text {crit }}\right)$ (Lamanna et al., 1973) has been proposed for bacterial growth at low temperatures to explain the transition between optimal and sub-optimal thermal activity ranges (Guillou and Guespin-Michel, 1996). A $T_{\text {crit }}$ has also been described for thermophilic, mesophilic and psychrotolerant microorganisms (Harder and Veldkamp, 1968; Mohr and Krawiec, 1980; Reichardt and Morita, 1982). The biochemical basis for $T_{\text {crit }}$ remains uncertain, but this temperature is likely the result of the uncoupling of DNA 
synthesis rate and growth rate at low temperatures (Bakermans and Nealson, 2004). Although a $T_{\text {crit }}$ has been described for pure isolates of sulfate-reducing bacteria (Tarpgaard et al., 2006), there have been no reports for natural communities of SRM in marine sediments.

In tropical sediments the $T_{\text {crit }}$ was close to the respective in situ temperatures and much higher than in polar and temperate sediments, where the linear temperature dependence of SRR extended down to $-10^{\circ} \mathrm{C}$ and showed no evidence of a lowtemperature threshold (Figure 4). The low $T_{\text {crit }}$ in the Arctic sediment likely reflected the physicochemical constraints (that is, ice crystallization, high salinity and low nutrient availability) imposed by sediment freezing. Our results show that sulfate-reducing communities in these cold habitats can tolerate temperatures down to or below the freezing point of seawater, which may permit survival and recovery after temporary freezing of the sediment. Studies of Arctic sediments show that sulfate reduction decreases strongly during freezing, yet SRM may exhibit relatively high metabolic rates immediately upon thawing, even after repeated freeze-thaw cycles (Sawicka et al., 2010). Water on mineral surfaces and in liquid veins in ice can provide adequate habitats for active microbial populations (Price, 2007; Bowman et al., 2012; Ewert and Deming, 2014). Moreover, there is no evidence of a minimum temperature for metabolism even at temperatures as low as $-20^{\circ} \mathrm{C}$ (Rivkina et al., 2000). In addition to psychrophily, cryotolerance (for example, D'Amico et al., 2006) may be an important characteristic of SRM for survival in polar coastal environments that freeze during winter. The larger difference between the $T_{\text {opt }}$ and the $T_{\text {crit }}$ in the polar and temperate habitats shows that the active SRM consist of a mixture of divergent temperature adaptations that may include psychrophiles, psychrotolerants and mesophiles, whereas in the tropical habitats a more narrowly adapted mesophilic community is present.

While the overall phylotype composition of the SRM communities is unique at each site, certain phylotypes are specific to warm or cold regions (Figure 7 and Supplementary Figure S2). Notably, sediments from the geographically distant Arctic and Antarctic hosted microbial communities that are more similar to each other than to geographically closer low-latitude sediments from, for example, the Arabian Sea (Goa) or the southern North Sea (Dangast). This provides further evidence that the SRM diversity is largely controlled and maintained by effects of ambient temperatures.

\section{Conclusions}

The combination of our respiration rate measurements with phylogenetic community analysis of different climatic regions shows that physiological temperature adaptations allow certain SRM to capitalize on their respective environmental thermal range thus selecting for different SRM and structuring community diversity. This implies that, as the different thermal SRM groups grow and metabolize effectively at their corresponding ambient temperatures, a high specific sedimentary carbon mineralization rate is possible in all environments. Indeed, process studies in Arctic sediments revealed sulfate reduction rates that were as high as SRR in temperate sediments (Sagemann et al., 1998) implying significant functional redundancy of seabed microbial communities at all temperatures. An intriguing implication is therefore that changes in microbial community composition that could arise in response to increasing ambient temperatures may not result in higher carbon mineralization rates on the long term, because microbial communities always thrive to optimize the metabolic rate under the prevailing temperature regime.

\section{Conflict of Interest}

The authors declare no conflict of interest.

\section{Acknowledgements}

We thank Mohammad Al-Najjar, Naik Hema, Moritz Holtappels, Erik Kristensen, Uwe Krumme, SWA Naqvi and Helge Niemann for sediment samples, and Kirsten Imhoff, Anna Kaufmann, Susanne Schwarz and Katharina Zyromski for assistance in the laboratory. This work was supported through the DFG Priority Program 1162 'The impact of climate variability on aquatic ecosystems (Aquashift)' (grants BR-2174-1.1 and BR 2174-1.2 to VB), the Austrian Science Fund (FWF project P25111-B22 to AL) and the Max Planck Society.

\section{References}

Abed RMM, Polerecky L, Al Najjar M, de Beer D. (2006). Effect of temperature on photosynthesis, oxygen consumption and sulfide production in an extremely hypersaline cyanobacterial mat. Aquat Microb Ecol 44: 21-30.

Aller RC, Yingst JY. (1980). Relationships between microbial distributions and the anaerobic aecomposition of organic-matter in surface sediments of Long-Island Sound, USA. Mar Biol 56: 29-42.

Anderson MJ. (2001). A new method for non-parametric multivariate analysis of variance. Aust Ecol 26: 32-46.

Arnosti C, Jørgensen BB, Sagemann J, Thamdrup B. (1998). Temperature dependence of microbial degradation of organic matter in marine sediments: polysaccharide hydrolysis, oxygen consumption, and sulfate reduction. Mar Ecol Prog Ser 165: 59-70.

Arrhenius S. (1908). Immunochemie. Ergebnisse Physiol 7: 480-551.

Bakermans C, Nealson KH. (2004). Relationship of critical temperature to macromolecular synthesis and growth yield in Psychrobacter cryopegella. J Bacteriol 186: 2340-2345. 
Battley EH. (1964). Thermal-gradient block for determination of temperature relationships in microorganisms. Anton Van Leeuwenhoek 30: 81-96.

Benjamini Y, Hochberg Y. (1995). Controlling the false discovery rate - a practical and powerful approach to multiple testing. $J R$ Stat Soc Ser B Methodol 57: 289-300.

Bowman JS, Rasmussen S, Blom N, Deming JW, Rysgaard S, Sicheritz-Ponten T. (2012). Microbial community structure of Arctic multiyear sea ice and surface seawater by 454 sequencing of the $16 \mathrm{~S}$ RNA gene. ISME J 6: 11-20.

Bryant MP. (1972). Commentary on hungate technique for culture of anaerobic bacteria. Am J Clin Nutr 25: 1324-1328.

Canion A, Kostka JE, Gihring TM, Huettel M, van Beusekom JEE, Gao $\mathrm{H}$ et al. (2014). Temperature response of denitrification and anammox reveals the adaptation of microbial communities to in situ temperatures in permeable marine sediments that span 50 degrees in latitude. Biogeosciences 11: 309-320.

D'Amico S, Claverie P, Collins T, Georlette D, Gratia E, Hoyoux A et al. (2002). Molecular basis of cold adaptation. Philos Trans $R$ Soc Lond B Biol Sci 357: 917-925.

D'Amico S, Collins T, Marx JC, Feller G, Gerday C. (2006). Psychrophilic microorganisms: challenges for life. EMBO Rep 7: 385-389.

de Rezende JR, Kjeldsen KU, Hubert CRJ, Finster K, Loy A, Jorgensen BB. (2013). Dispersal of thermophilic Desulfotomaculum endospores into Baltic Sea sediments over thousands of years. ISME J 7: 72-84

Edgar RC. (2010). Search and clustering orders of magnitude faster than BLAST. Bioinformatics 26: 2460-2461.

Ewert M, Deming JW. (2014). Bacterial responses to fluctuations and extremes in temperature and brine salinity at the surface of Arctic winter sea ice. FEMS Microbiol Ecol 89: 476-489.

Fuhrman JA. (2009). Microbial community structure and its functional implications. Nature 459: 193-199.

Guillou C, Guespin-Michel JF. (1996). Evidence for two domains of growth temperature for the psychrotrophic bacterium Pseudomonas fluorescens MF0. Appl Environ Microbiol 62: 3319-3324.

Haas BJ, Gevers D, Earl AM, Feldgarden M, Ward DV, Giannoukos G et al. (2011). Chimeric $16 \mathrm{~S}$ rRNA sequence formation and detection in Sanger and 454-pyrosequenced PCR amplicons. Genome Res 21: 494-504.

Hanson CA, Fuhrman JA, Horner-Devine MC, Martiny JBH. (2012). Beyond biogeographic patterns: processes shaping the microbial landscape. Nat Rev Microbiol 10: $497-506$.

Harder W, Veldkamp H (1968). Physiology of an obligately psychrophilic marine Pseudomonas species. J Appl Bacteriol 31: 12.

Hoehler TM, Jørgensen BB. (2013). Microbial life under extreme energy limitation. Nat Rev Microbiol 11: 83-94.

Holmkvist L, Kamyshny Jr A, Brüchert V, Ferdelman TG, Jørgensen BB. (2014). Sulfidization of lacustrine glacial clay upon Holocene marine transgression (Arkona Basin, Baltic Sea). Geochim Cosmochim Acta 142: 75-94.

Hubert C, Loy A, Nickel M, Arnosti C, Baranyi C, Bruchert $\mathrm{V}$ et al. (2009). A constant flux of diverse thermophilic bacteria into the cold arctic seabed Science 325: 1541-1544.

Isaksen MF, Bak F, Jørgensen BB. (1994). Thermophilic sulfate-reducing bacteria in cold marine sediment. FEMS Microbiol Ecol 14: 1-8.

Isaksen MF, Jørgensen BB. (1996). Adaptation of psychrophilic and psychrotrophic sulfate-reducing bacteria to permanently cold marine environments. Appl Environ Microbiol 62: 408-414.

Jørgensen BB. (1977). Sulfur cycle of a coastal marine sediment (Limfjorden, Denmark). Limnol Oceanogr 22: 814-832.

Kallmeyer J, Ferdelman TG, Weber A, Fossing H, Jørgensen BB. (2004). A cold chromium distillation procedure for radiolabeled sulfide applied to sulfate reduction measurements. Limnol Oceanogr Meth 2: 171-180.

Kjeldsen KU, Loy A, Jakobsen TF, Thomsen TR, Wagner M, Ingvorsen K. (2007). Diversity of sulfatereducing bacteria from an extreme hypersaline sediment, Great Salt Lake (Utah). FEMS Microbiol Ecol 60: 287-298.

Knoblauch C, Jørgensen BB. (1999). Effect of temperature on sulphate reduction, growth rate and growth yield in five psychrophilic sulphate-reducing bacteria from Arctic sediments. Environ Microbiol 1: 457-467.

Kostka JE, Thamdrup B, Glud RN, Canfield DE. (1999). Rates and pathways of carbon oxidation in permanently cold Arctic sediments. Mar Ecol Prog Ser 180: 7-21.

Kristensen E, Bodenbender J, Jensen MH, Rennenberg H, Jensen KM. (2000). Sulfur cycling of intertidal Wadden Sea sediments (Konigshafen, Island of Sylt, Germany): sulfate reduction and sulfur gas emission. J Sea Res 43: 93-104.

Kristensen E, Bouillon S, Dittmar T, Marchand C. (2008). Organic carbon dynamics in mangrove ecosystems: a review. Aquat Bot 89: 201-219.

Lamanna C, Mallette MF, Zimmerman LN. (1973). Basic Bacteriology Its Biological and Chemical Background 4th edn. Williams \& Wilkins, Baltimore, MD.

Leloup J, Fossing H, Kohls K, Holmkvist L, Borowski C, Jørgensen BB. (2009). Sulfate-reducing bacteria in marine sediment (Aarhus Bay, Denmark): abundance and diversity related to geochemical zonation. Environ Microbiol 11: 1278-1291.

Leloup J, Loy A, Knab NJ, Borowski C, Wagner M, Jørgensen BB. (2007). Diversity and abundance of sulfate-reducing microorganisms in the sulfate and methane zones of a marine sediment, Black Sea. Environ Microbiol 9: 131-142.

Ludwig W, Strunk O, Westram R, Richter L, Meier H, Yadhukumar et al. (2004). ARB: a software environment for sequence data. Nucleic Acids Res 32: 1363-1371.

Marx JC, Collins T, D'Amico S, Feller G, Gerday C. (2007). Cold-adapted enzymes from marine antarctic microorganisms. Mar Biotechnol 9: 293-304.

Mazumdar A, Paropkari AL, Borole DV, Rao BR, Khadge NH, Karisiddaiah SM et al. (2007). Pore-water sulfate concentration profiles of sediment cores from Krishna-Godavari and Goa basins, India. Geochem J 41: 259-269.

Moeslund L, Thamdrup B, Jørgensen BB. (1994). Sulfur and iron cycling in a coastal sediment: Radiotracer 
studies and seasonal dynamics. Biogeochemistry 27: 129-152.

Mohr PW, Krawiec S. (1980). Temperature characteristics and Arrhenius plots for nominal psychrophiles, mesophiles and thermophiles. Microbiology 121: 311-317.

Morita RY. (1975). Psychrophilic bacteria. Bacteriol Rev 39: $144-167$.

Müller AL, Kjeldsen KU, Rattei T, Pester M, Loy A. (2014a). Phylogenetic and environmental diversity of DsrAB-type dissimilatory (bi)sulfite reductases. ISME J 9: 1152-1165.

Müller AL, de Rezende JR, Hubert CRJ, Kjeldsen KU, Lagkouvardos I, Berry D et al. (2014b). Endospores of thermophilic bacteria as tracers of microbial dispersal by ocean currents. ISME J 8: 1153-1165.

Neidhardt FC, Ingraham JL, Schaechter M (1990). Physiology of the Bacterial Cell: A Molecular Approach. Sunderland, MA: Sinauer Associates.

Niemann H, Fischer D, Graffe D, Knittel K, Montiel A, Heilmayer O et al. (2009). Biogeochemistry of a lowactivity cold seep in the Larsen B area, western Weddell Sea, Antarctica. Biogeosciences 6: 2383-2395.

Oksanen J, Blanchet FG, Kindt R, Legendre P, Minchin PR, O'Hara RB et al. (2012), Vegan: Community Ecology Package. $\mathrm{R}$ package version 2.0-3.

Pomeroy LR, Wiebe WJ. (2001). Temperature and substrates as interactive limiting factors for marine heterotrophic bacteria. Aquat Microb Ecol 23: 187-204.

Price PB. (2007). Microbial life in glacial ice and implications for a cold origin of life. FEMS Microbiol Ecol 59: 217-231.

Prosser JI, Bohannan BJM, Curtis TP, Ellis RJ, Firestone MK, Freckleton RP et al. (2007). The role of ecological theory in microbial ecology. Nat Rev Microbiol 5: 384-392.

Pruesse E, Peplies J, Glöckner FO. (2012). SINA: Accurate high-throughput multiple sequence alignment of ribosomal RNA genes. Bioinformatics 28: 1823-1829.

Quast C, Pruesse E, Yilmaz P, Gerken J, Schweer T, Yarza P et al. (2013). The SILVA ribosomal RNA gene database project: improved data processing and web-based tools. Nucleic Acids Res 41: D590-D596.

Ravenschlag K, Sahm K, Pernthaler J, Amann R. (1999). High bacterial diversity in permanently cold marine sediments. Appl Environ Microbiol 65: 3982-3989.

Reichardt W, Morita RY. (1982). Temperature characteristics of psychrotrophic and psychrophilic bacteria. J Gen Microbiol 128: 565-568.

Rivkina EM, Friedmann EI, McKay CP, Gilichinsky DA. (2000). Metabolic activity of permafrost bacteria below the freezing point. Appl Environ Microbiol 66: 3230-3233.

Robador A, Brüchert V, Jørgensen BB. (2009). The impact of temperature change on the activity and community composition of sulfate-reducing bacteria in arctic versus temperate marine sediments. Environ Microbiol 11: 1692-1703.

Roy H, Weber HS, Tarpgaard IH, Ferdelman TG, Jørgensen BB. (2014). Determination of dissimilatory sulfate reduction rates in marine sediment via radioactive S-35 tracer. Limnol Oceanogr Meth 12: 196-211.

Sagemann J, Jørgensen BB, Greeff O. (1998). Temperature dependence and rates of sulfate reduction in cold sediments of Svalbard, Arctic Ocean. Geomicrobiol J 15: $85-100$.

Saito R, Smoot ME, Ono K, Ruscheinski J, Wang PL, Lotia S et al. (2012). A travel guide to Cytoscape plugins. Nat Methods 9: 1069-1076.

Sawicka JE, Jørgensen BB, Brüchert V. (2012). Temperature characteristics of bacterial sulfate reduction in continental shelf and slope sediments. Biogeosciences 9: 3425-3435.

Sawicka JE, Robador A, Hubert C, Jørgensen BB, Brüchert V. (2010). Effects of freeze-thaw cycles on anaerobic microbial processes in an Arctic intertidal mud flat. ISME J 4: 585-594.

Schloss PD, Westcott SL, Ryabin T, Hall JR, Hartmann M, Hollister EB et al. (2009). Introducing mothur: OpenSource, platform-independent, community-supported software for describing and comparing microbial communities. Appl Environ Microbiol 75: 7537-7541.

Tarpgaard IH, Boetius A, Finster K. (2006). Desulfobacter psychrotolerans sp nov., a new psychrotolerant sulfate-reducing bacterium and descriptions of its physiological response to temperature changes. Anton Van Leeuwenhoek 89: 109-124.

Team RDC. (2011). R: A Language and Environment for Statistical Computing. The R Foundation for Statistical Computing: Vienna, Austria.

Walczowski W, Piechura J. (2007). Pathways of the Greenland Sea warming. Geophys Res Lett 34: L10608.

Wang Q, Garrity GM, Tiedje JM, Cole JR. (2007). Naive Bayesian classifier for rapid assignment of rRNA sequences into the new bacterial taxonomy. Appl Environ Microbiol 73: 5261-5267.

Westrich JT, Berner RA. (1988). The effect of temperature on rates of sulfate reduction in marine sediments. Geomicrobiol J 6: 99-117.

Widdel F, Bak F. (1992). Gram-negative mesophilic sulfate-reducing bacteria. In: Balows A, Trüper HG, Dworking $\mathrm{M}$, Harder $\mathrm{W}$, Schleifer K-H (eds). The Prokaryotes 2nd edn. Springer: New York.

Xu XM, Fu SY, Zhu Q, Xiao X, Yuan JP, Peng J et al. (2014). Depth-related coupling relation between methaneoxidizing bacteria (MOBs) and sulfate-reducing bacteria (SRBs) in a marine sediment core from the Dongsha region, the South China Sea. Appl Microbiol Biotechnol 98: 10223-10230.

Supplementary Information accompanies this paper on The ISME Journal website (http://www.nature.com/ismej) 